\title{
As heroínas histéricas e vampíricas de Aluísio Azevedo
}

Hysterical heroines and vampiric stories by Aluísio Azevedo

Hélder Brinate Castro

UFRJ/CAp-UFRJ

\begin{abstract}
Resumo
Este trabalho objetiva investigar, na prosa naturalista eivada por influxos da poética gótica, a personagem feminina, comumente descrita como vítima da histeria. Reavaliam-se, assim, tanto o Gótico, compreendido como uma poética que consubstancia uma interpretação pessimista do mundo em uma linguagem artística altamente estetizada, quanto o Naturalismo, cuja pretensão objetivo-científica mescla-se com heranças românticas e revela uma desilusão com os avanços científicos. Debruça-se ainda sobre o conto "Músculos e nervos" (1893) e sobre o romance $O$ bomem (1887), ambos de Aluísio Azevedo, de forma a analisar as figurações da personagem histérica na literatura brasileira.

Palavras-chave: Gótico; Naturalismo; literatura brasileira
\end{abstract}

\begin{abstract}
This essay aims to analyse the hysterical female character in naturalistic prose influenced by Gothic poetics. For this, we reassess both Gothic and Naturalism. While the first is understood as a poetics that embodies a pessimistic interpretation of the world in a highly aestheticized artistic language, the second has its objectivescientific pretension and its blends with romantic heritages reanalysed. To investigate the figurations of the hysterical character in Brazilian literature, we also studied the short story "Muscles and nerves" (1893) and the novel $O$ bomem (1887), both by Aluísio Azevedo.

Keywords: Gothic; Naturalism; Brazilian literature
\end{abstract}




\title{
Introdução
}

Pode parecer disparatado associar a literatura brasileira à gótica. A aparente contradição pauta-se, sobretudo, no fato de grande parte de nossa crítica literária considerar as ambientações e as temáticas da poética gótica exógenas à cultura e ao território nacional. As florestas tenebrosas, os castelos e os casarões arruinados, as colinas e os declives assombrosos seriam incompatíveis com a natureza do Brasil, considerada solar e deslumbrante. Tal perspectiva ecoa o julgamento literário propagado no início do século XIX de que havia uma necessária relação entre a literatura, a geografia e o temperamento da população de determinado país, como podemos aferir a partir da proposição de Mme. de Staël:

\begin{abstract}
Os poetas do meio-dia combinam sem parar a imagem do frescor, dos bosques frondosos, dos límpidos riachos com todos os sentimentos da vida. Nem os prazeres do coração eles evocam sem com eles combinar a ideia de sombra benfazeja, que deve protegê-los dos ardores impetuosos do sol. Aquela natureza tão vívida que os rodeia desperta neles mais ações que pensamentos. [...] Os povos do norte se ocupam menos com os prazeres do que com a dor, e sua imaginação por isso é mais fecunda. $\mathrm{O}$ espetáculo da natureza age fortemente sobre eles; ela age como se mostra naqueles climas, sempre sombria e nebulosa. Sem dúvida, as diversas circunstâncias da vida podem modificar essa disposição para a melancolia; mas ela detém com exclusividade a marca do espírito nacional ${ }^{1}$.
\end{abstract}

A suposta incoerência da associação entre a poética gótica e a nossa literatura respalda-se ainda na tendência de a historiografia literária brasileira privilegiar o caráter documental em detrimento do imaginativo. Nossa escrita manifestar-se-ia como mais propensa e preocupada com uma abordagem realista do mundo representado, pretendendo-se o mais documental possível e atendo-se mais à observação que à imaginação. O Gótico, ao explorar eventos sobrenaturais - explicados ou não -, figurações, simbologias e personagens ameaçadoras para a constituição de enredos aterrorizantes, distanciar-se-ia da expectativa de arte mimética assumida por nossa crítica tradicional.

Seria, então, insustentável comparar aspectos de obras brasileiras com de obras góticas? Não existiriam, em nossas Letras, textos com traços da poética gótica? Tais questões tornam-se ainda mais complexas quando se associam ao Naturalismo, amplamente reconhecido por alicerçar seus fundamentos estéticos em declarações científicas, tencionando elaborar, em ficção, documentos da realidade.

Para respondermos a essas questões, faz-se mister, por um lado, uma reavaliação da poética gótica, não a limitando a suas formas e fórmulas rocambolescas do Setecentos, mas a compreendendo como um fenômeno moderno que coaduna uma forma artística altamente estetizada e convencionalista com uma visão de mundo negativa e desiludida com a realidade. Por outro, é necessária uma investigação da pretensão realista que perpassa a literatura brasileira, sobretudo o período naturalista, reexaminando

1 STAËL, Mme de. "Sobre as literaturas do norte e do meio dia", 2011, p. 82. 
os aspectos tributários à imaginação romântica e à intensificação, por meio da intenção científica, do caráter bestial do homem.

\section{O Gótico no Brasil}

No campo dos estudos literários, costuma-se compreender o Gótico de acordo com duas perspectivas: uma que o considera como um gênero historicamente determinado, e outra, como uma tendência mais persistente e abrangente dentro da ficção como um todo. Conforme a primeira compreensão, o Gótico é um fenômeno histórico-literário, cujo auge, situado entre a segunda metade do século XVIII e o início do XIX, caracteriza-se pela produção de uma ficção popular associada a uma visão sombria e decadente da vida, em que escritores como Ann Radcliffe deixaram sua marca. Tal concepção não impossibilita, porém, a manifestação de revivalismos góticos nos séculos posteriores, pois, conforme David Stevens $^{2}$, o próprio Gótico Setecentista teria sido um revivalismo de temáticas medievais e fantasiosas.

A segunda perspectiva, por sua vez, considera o Gótico menos como um movimento artístico restrito a locais e momentos históricos específicos e mais como uma disposição do espírito moderno que alterou, significativamente, os modos de pensar, sentir e expressar a arte na modernidade. Trata-se, pois, de um fenômeno transcultural caracterizado por uma visão de mundo negativa e desiludida. Compartilhando desta concepção, Júlio França ${ }^{3}$ afirma que o Gótico é a amálgama entre uma interpretação pessimista do mundo e uma linguagem artística altamente estetizada que, despontada na segunda metade do século XVIII, teria se adaptado, em seus diversos revivalismos, às ansiedades e aos medos da sociedade moderna. Tais apreensões são amplamente exploradas na literatura, como declara Fred Botting:

A bondade, seja em termos morais, estéticos ou sociais, não se faz presente nos textos góticos. É o vício que lhe interessa: os protagonistas são egoístas ou maus; as tramas envolvem decadência ou crime. Seus efeitos, estéticos e sociais são repletos de características negativas - não há beleza, nem demonstrações de harmonia ou proporção. Deformados, obscuros, feios, lúgubres e completamente avessos aos efeitos do amor, da afeição ou dos prazeres nobres, os textos góticos inscrevem a repulsa, o ódio, o medo, a aversão e o terror ${ }^{4}$.

A partir dessa segunda compreensão, estudos recentes vêm demonstrando que a produção ficcional brasileira apresenta influxos da poética gótica, muitas vezes incompreendidos e menosprezados pela crítica nacional. França ${ }^{5}$ identifica um complexo de fatores para o "sequestro" da poética gótica das Letras nacionais, entre os quais se destacam a preferência de nossos estudos literários por temas

2 STEVENS, David. The Gothic tradition, 2000, p. 19.

3 FRANÇA, Júlio. "Introdução", 2017, p. 22.

4 BOTTING, Fred. Gotbic, 2014, p. 2. Tradução nossa.

5 FRANÇA, Júlio. "Introdução", 2017, p. 22. 
realistas e explicitamente relacionados à identidade nacional; o pouco interesse da crítica por obras de cunho popular; e a inexistência de uma produção sistemática de narrativas góticas em nossa literatura. A recepção de Noite na taverna (1855), de Álvares de Azevedo, constitui caso exemplar: a predominância de análises biografistas e psicológicas, que se voltaram para o homem Álvares e não para sua obra, associaram os elementos góticos de sua escrita à personalidade melancólica do escritor. Além disso, acusou-se o autor de uma suposta alienação quanto aos temas da realidade brasileira. É somente a partir de 1931, com o ensaio "A originalidade de Álvares de Azevedo", de Afrânio Peixoto ${ }^{6}$, que se utiliza o termo "gótico" para se referir à obra do escritor romântico.

O episódio envolvendo o autor de Macário (1852) não configura evento exclusivo. Pesquisadores contemporâneos vêm vislumbrando influxos góticos em nossas Letras. Vasconcelos ${ }^{7}$ tem explorado a influência da poética gótica no Romantismo brasileiro, enquanto Meireles ${ }^{8}$ demonstra que tal influxo se estende, pelo menos, até meados do século XX. Mesmo o Naturalismo não escapou dessa influência, como indicam os trabalhos de Sena ${ }^{9}$. França ${ }^{10}$ constata ainda seis pontos de contato entre a poética gótica e as Letras brasileiras, a saber:

(i) As origens do romance no Brasil podem ter recebido influências do Gótico, uma vez que houve considerável circulação de romances ingleses no território brasileiro do início do século XIX;

(ii) A forma como nossos escritores naturalistas interpretaram as teorias de Darwin e de Taine proporcionou a criação de personagens descritas como monstruosidades e a percepção negativa de que o homem é guiado por seus instintos bestiais;

(iii) Influxos da literatura decadentista, como o desencanto com a modernidade e a recusa às tendências realistas, podem ser observados em autores que tematizaram perversões humanas, cujas consequências foram, não raro, a loucura e a morte;

(iv) A literatura de crime, fronteiriça entre o jornalismo e a ficção, conserva também elos com a poética gótica, cuja origem remonta ao nascimento dos romances policiais e das narrativas detetivescas;

(v) Os romances de sensação, imbricados entre as narrativas góticas e a ficção de crime, ao explorarem dramas repletos de transgressões aterrorizantes e eventos imprevisíveis, revelam os excessos tão caros ao Gótico;

6 PEIXOTO, Afrânio. "A originalidade de Álvares de Azevedo". Revista Nova, 1931, p. 355-374.

7 VASCONCELOS, Sandra. "Sentidos do demoníaco em José de Alencar", Ilba do Desterro, 2012, p. 271-292.

8 MEIRELES, Alexander. O admirável mundo novo da república velba: o nascimento da ficção científica brasileira no começo do século XX, 2008.

9 SENA, Marina Faria. O Gótico-Naturalismo na literatura brasileira oitocentista, 2017.

10 FRANÇA, Júlio. "Introdução", 2017, p. 31-34. 
(vi) A tradição regionalista apresenta narrativas que se utilizaram de recursos góticos para expressar o terror do imaginário popular e o horror da seca, da fome e da violência no interior do país.

Dos muitos pontos de contato entre a literatura brasileira e a gótica, há, ainda, cinco procedimentos que surgem como fundamentais: a construção de espaços narrativos como loci horribiles; a relação fantasmagórica com o passado, que ressurge para assombrar o presente; a caracterização de personagens como monstruosidades devido à própria natureza humana ou às psicopatologias; o desenvolvimento de enredos que exploram efeitos melodramáticos e emocionais; e a utilização contínua de campos semânticos relacionados à morbidez e à degeneração física e mental.

\section{O Naturalismo no Brasil}

Na segunda metade do século XIX, o Brasil foi marcado por profundas transformações nos âmbitos político, econômico, cultural e social, desestabilizando a antiga ordem imperial alicerçada em uma economia agrária e escravocrata. "A querela religiosa, a maçonaria e o clero, a guerra do Paraguai, os movimentos abolicionistas e republicanos"11 constituem alguns dos principais acontecimentos que organizaram contexto propício a uma industrialização e a uma incipiente burguesia, direcionando a nação brasileira a uma nova era, guiada, como se acreditava, pela máxima positivista de ordem e progresso.

Apesar de as ideias estruturantes do pensamento oitocentista, como o darwinismo e o socialismo, terem demorado mais de vinte anos para atravessar o Atlântico, o meio político brasileiro presenciou, desde meados do século, discussões efervescentes sobre, a exemplo, o abolicionismo e a república. $\mathrm{O}$ âmbito literário, por sua vez, manteve-se, majoritariamente, alheio às novas tendências, continuando a escrever consoante os postulados românticos. Conforme Pereira, foi somente quando o realismo europeu "se exagerou no naturalismo e ganhou aquela rigidez que facilitou o êxito retumbante de Zola em França e Eça de Queirós em Portugal [...] que se instalou [o Naturalismo] definitivamente aqui” ${ }^{12}$. A pesquisadora assevera, ademais, que a poética naturalista, por ter sido imposta pela moda aos escritores brasileiros, que continuavam essencialmente românticos, originou, em grande parte, obras medíocres e artificiais. O Naturalismo, na literatura brasileira, associa-se, pois, a uma ideia de importação da matriz europeia, essencialmente francesa.

A historiografia literária brasileira estabeleceu ainda como truísmo a declaração de que todo escritor comprometido com o movimento naturalista deveria seguir, à risca, os preceitos científicos e socializantes de Zola a fim de compor uma obra em perfeita harmonia e correspondência com a realidade imediata, conferindo à literatura a pretensa precisão de um relatório científico. A julgar por paratextos

11 BRAYNER, Sonia. "Naturalismo: uma ficção em crise", 1979, p. 16.

12 PEREIRA, Lúcia Miguel. História da literatura brasileira: prosa de ficção: de 1870 a 1920, 1988, p. 121.a 
de alguns de nossos autores, a preocupação para fazer da ficção espelho científico da realidade percorreu as páginas do Naturalismo brasileiro. Aluísio Azevedo, em O bomem (1887), declara que "Quem não amar a verdade na arte e não tiver a respeito do Naturalismo ideias bem seguras, fará, deixando de ler este livro, um grande obséquio a quem o escreveu"13. Em O Cortiço (1890), Azevedo utiliza-se, por sua vez, da seguinte epígrafe: "La Vérité, toute la vérité, rien que la vérité" ${ }^{14}$. Não nos esqueçamos de que Júlio Ribeiro dedica o romance A Carne (1888) "A M. Émile Zola"15. Tal pretensão pela realidade objetiva é bem resumida por Süssekind:

\footnotetext{
Quando se liam romances como $O$ Homem de Aluísio Azevedo ou A Carne de Júlio Ribeiro, a associação a monografias médicas sobre a histeria era inevitável. O que se lia como ficção, se dizia também ciência. Ler $O$ Homem equivalia a um estudo sobre os sintomas histéricos. Assim como ler $O$ Cortiço, segundo a crítica da época, talvez fosse o mesmo que "ver" um cortiço. O que se representava como ficção se apresentava também como documento ${ }^{16}$.
}

Devido à aguçada atenção ao real e à ciência, encontramos determinados topoi e estratégias narrativas recorrentes na ficção naturalista: (i) a tentativa de açambarcar todas as situações como sendo consecutivas e pertencentes a uma semiótica superior; (ii) uma constante caracterização anafórica, "na qual toda a identidade afirma-se como identificação de algo já conhecido"17; (iii) a presença de médicos ou estudantes de medicina como autoridade moral e/ou intelectual; (iv) a temática da histeria feminina embasada em pressupostos de Charcot; (v) a influência, de acordo com as ideais de Taine, do meio e da hereditariedade como elementos formadores de carácteres físicos e psicológicos; e (vi) a tendência atávica do criminoso para o mal tal qual anunciava a teoria de Lombroso.

O uso de técnicas narrativas e a exploração das Ciências, sobretudo, biológicas e psicológicas, não impediu, todavia, que romances e contos naturalistas distanciassem-se do ideal realista e científico. Bastante frequentes são os influxos românticos no Naturalismo. Em nossa literatura, a obra de Aluísio Azevedo constitui exemplo consciente, o que é percebido pela crítica como uma cisão na obra do escritor: temos um Aluísio folhetinesco e outro naturalista. Mesmo neste último, contrariando o que a crítica, afeita a um realismo exacerbado, entendia como Naturalismo, encontramos também reminiscências do Romantismo. Ao analisar romances naturalistas, entre eles $O$ mulato (1881), de Azevedo, Brayner revela a herança romântica:

13 AZEVEDO, Aluísio. O bomem, 1887, p. 5.

14 Idem. O Cortiço, 1975, p. 15.

15 RIBEIRO, Júlio. A Carne, 1896, n.p.

16 SÜSSEKIND, Flora. Tal Brasil, qual romance?, 1984, p. 65.

17 BRAYNER, Sonia. "Naturalismo: uma ficção em crise", 1979, p. 35. 


\begin{abstract}
O projeto realista-descritivo, cujo funcionamento prevê a utilização de artifícios narrativos que permitam ao texto inserir-se na transparência semântica do fluxo vital, estará no Naturalismo brasileiro sempre eivado de reminiscências românticas que lhe dissolvem os propósitos de objetividade e de exaustividade tão postulados por Zola ${ }^{18}$.
\end{abstract}

Dessa forma, o narrador neutro do Naturalismo cedeu, algumas vezes, lugar a um narrador moralizante, que, nas palavras de Bosi, além de possuir "um resíduo romântico [...] de perscrutar o excepcional, o feio, o grotesco"19, "carrega sempre de tons sombrios o destino de suas criaturas" ${ }^{20}$. Sodré constata também uma inclinação dos naturalistas para dramatizar o horrível e deformar a realidade, desvelando um constante pessimismo em sua prosa: trata-se da "desolação que assinala o naufrágio das aspirações humanas, a tristeza monótona da irremediável mediocridade, peculiares a uma classe em decadência"”1.

Ao invés de uma literatura exclusivamente objetiva e científica, o Naturalismo brasileiro manifestou-se de forma mais complexa. Conformaram-se narrativas híbridas entre a subjetividade e a imaginação rocambolesca do Romantismo e a pretensa reprodução objetiva da realidade apreendida pelos olhares dos narradores naturalistas. O projeto naturalista dista, pois, de sua própria concretização ficcional. Impregnado por um pessimismo, o Naturalismo brasileiro não se limita a uma tendência artística que apenas almeja representar fielmente a realidade. Tal poética, por meio do seu hibridismo realístico-científico-romântico, ressalta a bestialidade humana, que se concretiza em personagens monstruosas, praticantes ou vítimas de comportamentos transgressores, como as perversões, e as violações sexuais, temáticas tão caras ao Gótico.

\title{
A poética gótico-naturalista
}

A constatação de confluências entre o Gótico e o Naturalismo e de uma poética híbrida entre eles, o Gótico-Naturalismo, enceta uma aparente contradição. A poética gótica e a naturalista têm, de fato, origens díspares: enquanto a primeira manifesta um acentuado desencanto com a modernidade e questiona intensamente os discursos da razão, sejam eles iluministas ou positivistas, a segunda alicerça-se em pressupostos científicos com a intenção de escrever, em ficção, documentos da realidade.

A historiografia literária vem demonstrando, contudo, que a pretensão pela objetividade e pelo discurso científico da prosa naturalista encontra-se, frequentemente, mesclada com a sub-

18 Ibidem, p. 43.

19 BOSI, Alfredo. História concisa da literatura brasileira, 2015, p. 182.

20 Ibidem, p. 183.

21 SODRÉ, Nelson Werneck. O Naturalismo no Brasil, 1965, p. 39. 
jetividade moralista de um narrador romântico e com a trama rocambolesca e romanesca dos folhetins. O escritor naturalista não endossava, assim, a neutralidade científica. Em sua pena, o lado lúgubre da ciência ganhava contornos definidos, sublinhando a bestialidade da humanidade. Em relação aos estudos de Charles Darwin, Baguley discorre que:

\begin{abstract}
Tem sido frequentemente notado que, enquanto cientistas, filósofos e historiadores [do século XIX] eram inclinados a enxergar o Darwinismo a partir de uma ótica otimista, e a imaginação popular via, na teoria da evolução, nova justificativa para uma crença otimista no progresso da humanidade, os romancistas adotaram uma visão mais pessimista. Eles tendiam a se apoderar de uma visão de que o homem estaria subjugado por impulsos irreprimíveis, de que ele reagiria mecanicamente às necessidades biológicas: o homem seria movido por instintos básicos de alimentação, sexo, violência, regulado pelo meio, pela hereditariedade e por impulsos ainda mais primitivos, sendo estimulado ou derrotado pela implacável competitividade da vida. Para os naturalistas, a própria espécie humana estava se tornando não menos selvagem do que qualquer outra espécie do reino animal. Os conceitos marxistas e spencerianos de determinismo social e econômico, deduzidos do trabalho de Darwin, reforçavam essa percepçã $0^{22}$.
\end{abstract}

Não apenas os escritores naturalistas interpretaram de forma sombria as novas teorias científicas oitocentistas. Teóricos do Gótico, como Anolik e Botting, discutem também os impactos dos avanços científicos na ficção de autores do Oitocentos que se debruçaram sobre essa poética. Enquanto Botting é mais abrangente, apontando que as descobertas feitas pelos cientistas geraram "não só um novo vocabulário como também novos objetos de medo e de ansiedade para a ficção gótica do século XIX"23, Anolik explica que as criaturas sobrenaturais do Gótico Setecentista foram substituídas pelo Gothic Other: "os fantasmas e os monstros, explicados e deslocados pela ciência, pelas transformações e pelas descobertas, não desapareceram; eles foram realocados para novos espaços sombrios, além das 'fronteiras da consciência e das políticas social, racial e de gênero"'24. Estabelece-se, portanto, o principal ponto de contato entre o Naturalismo e a literatura gótica finissecular: ambos "tendiam a tematizar em suas obras as consequências mais cruéis dos novos conceitos e ideias da medicina e da ciência de modo geral" ${ }^{25}$.

A partir de uma perspectiva lúgubre quanto à ciência e desencantada quanto aos seus avanços, os escritores naturalistas focalizaram, sob lentes pessimistas, os impulsos mais primitivos do homem. Orientados por seus intuitos pretensamente científicos e por suas interpretações limitadas das teorias de Darwin, Taine, Lombroso e Charcot, os ficcionistas fizeram

22 BAGULEY, David. Naturalist fiction; the entropic vision, 1990, p. 216-217. Tradução nossa.

23 BOTTING, Fred. Gotbic, 2014, p. 12. Tradução nossa.

24 ANOLIK, Ruth Bienstock. "Introduction", 2004, p. 2. Tradução nossa.

25 SENA, Marina Faria. O Gótico-Naturalismo na literatura brasileira oitocentista, 2017, p. 54. 
emergir personagens que, subjugadas por seus instintos e sedentas por prazeres desmedidos do sexo e do sangue, sofrem uma queda vertiginosa rumo à desumanização. Brayner aponta ainda que "obsessões eróticas assumem o papel de um corpo sempre desejado e renegado ao determinismo pessimista de uma literatura triste" ${ }^{26}$. Assim, mulheres, caso se abstivessem dos gozos da carne, tornavam-se histéricas e terminavam as narrativas estigmatizadas: loucas, prostituídas ou mortas. Homens e mulheres negros ou miscigenados possuíam, não raro, uma acentuada sensualidade e uma libido incontrolável, capazes de arrebatar qualquer vítima. A cor da pele e a etnia determinavam também a propensão para práticas de crimes atrozes e sanguinolentos: "homens miscigenados estavam fatalmente destinados a serem assassinos e criminosos" ${ }^{27}$. Arquitetando seus enredos a partir de métodos e propósitos científicos, os narradores naturalistas, além de focalizarem o pretendido caráter verdadeiro de suas tramas, destacavam as ações subversivas e transgressoras de suas personagens, que encontravam, várias vezes, um fim moralmente condenável.

A mácula desencantada e gótica sobre a pretensa neutralidade da ficção naturalista desvela a inquietante compreensão de que as luzes positivistas apenas iluminavam a sombria brutalidade humana, sendo incapazes de redimir nossa bestialidade. A humanidade estaria destinada a uma queda ao mais baixo nível da animalização. Dessa forma, as técnicas narrativas do Naturalismo são empregadas "menos para espelhar a realidade por meio de um discurso mimético, neutro e científico, e mais para representar os medos gerados pela percepção, por uma perspectiva científica - e pessimista - dessa mesma realidade" ${ }^{28}$. Conforma-se, assim, o Gótico-Naturalismo:

\footnotetext{
Gótico-Naturalismo, a princípio, parece um oximoro, uma impossibilidade óbvia [...]. Embora o Naturalismo raramente seja o livro objetivo de casos que almeja ser, um de seus traços de assinatura parece ser a facilidade com que se combina, em sua hibridez, com outras formas: o melodrama doméstico, a fábula moral, a história de aventura infantil - e o Gótico. Até nos romances de Émile Zola, o mestre da tradição naturalista, reconhecemos momentos tipicamente góticos: a morte de Nana ou a cena na mina inundada e o final de Germinal, em que o corpo de Chaval retorna constantemente, flutuando, para seu assassino, Etienne - uma sequência digna de Poe $^{29}$.
}

Por meio da tradição gótica, escritores naturalistas encontraram, pois, forma de expressar uma compreensão desiludida e pessimista frente à realidade da segunda metade do século XIX. As narrativas foram povoadas por personagens que, ao transgredirem fronteiras sociais e morais,

26 BRAYNER, Sonia. "Naturalismo: uma ficção em crise", 1979, p. 48.

27 SENA, Marina Faria. O Gótico-Naturalismo na literatura brasileira oitocentista, 2017, p. 54.

28 Ibidem, p. 55.

29 CROW, Charles. Jack London's The Sea Wolf as Gothic Romance, 1994, p. 123. Tradução nossa. 
fundamentalmente devido a psicopatologias hereditárias, transformaram-se em figuras monstruosas. As histéricas, deturpados os pensamentos de Charcot, são mulheres ameaçadoras e perigosas à organização social; e os negros e miscigenados, deturpadas as teorias de Lombroso, são atavicamente predispostos à perversidade e à crueldade. Tais monstruosidades habitam ambientes que funcionam não apenas como palco no qual ocorrem as violações, mas que também são responsáveis por conformar a atmosfera sombria e ameaçadora do enredo e por refletir e/ou ampliar o estado interior das personagens: eis o locus horribilis gótico ecoando o determinismo de Taine ao definir o caráter das personagens. O vocabulário científico do Naturalismo funde-se também à linguagem tétrica e estetizada do Gótico, configurando descrições em que os termos técnicos realçam a degeneração física e psicológica, engendrando o horror e a repulsa como efeitos estéticos. Na poética gótico-naturalista, o lado sombrio da ciência é explorado a fim de evidenciar as apreensões e as ansiedades de uma sociedade que se modernizava.

\section{A maldição feminina: a histeria}

A figura feminina vem exercendo fascínio em inúmeras culturas. Ora sacralizada, anunciadora da vida, ora demonizada, mensageira da morte, a mulher é tematizada, desde a Antiguidade, em lendas, mitos, crenças religiosas etc., ganhando importância também nas artes. Delumeau constata, a exemplo, essa dualidade já no culto às deusas-mães:

\footnotetext{
Essa ambiguidade fundamental da mulher que dá vida e anuncia a morte foi sentida ao longo dos séculos, e especialmente expressa pelo culto das deusas-mães. A terra mãe é o ventre nutridor, mas também o reino dos mortos sob o solo ou na água profunda. É cálice de vida e de morte. [...]. Daí as múltiplas lendas e representações de monstros fêmeas ${ }^{30}$.
}

O caráter dual faz da mulher um ser imprevisível: a maldade, o vício e a perversão podem aflorar diversificada e abruptamente da mesma forma como se pode conceber esperança por meio da formação de uma nova vida. Como observa Dottin-Orsini, "a mulher [...] é [...], naturalmente, destinada à falsidade e à crueldade, à mentira pronta e a mãos manchadas de sangue" ${ }^{31}$. Imbuída nesse universo, a literatura deparou-se com um farto acervo de formas e matizes para tematizar a dualidade feminina. No Gótico Setecentista, a exemplo, podemos encontrar essa dicotomia entre Emily e Agnes em Os mistérios de Udolpho (1794), de Ann Radcliffe, e entre Antonia e Matilda em $O$ monge (1796), de Matthew Lewis. Emily e Antonia, as heroínas das

30 DELUMEAU, Jean. História do medo no Ocidente; 1300 - 1800, 2001, p. 312.

31 DOTTIN-ORSINI, Mireille. A mulher que eles chamavam fatal; textos e imagens da misoginia finde-siècle, 1996, p. 14. 
narrativas, enquadram-se na figura de damsel in distress: a primeira enfrenta inúmeras ameaças em seu claustro no Castelo de Udolpho - dos assédios do Conde Morano à perversidade e à misoginia do signor Montoni; a segunda é estuprada e assassinada pelo padre Ambrósio no subsolo do Convento de St. Clare. Já Agnes e Matilda encarnam a face funesta da mulher: aquela, assombrada e enlouquecida por seus erros do passado, termina seus dias na clausura de um convento; esta, verdadeira femme fatale, auxilia Ambrósio em seu plano para violentar Antonia.

A literatura da segunda metade do século XIX, sobretudo a naturalista, ao ser guiada por um cientificismo misógino, atém-se ao lado ameaçador da figura feminina e "mostra claramente que a mulher mete medo, que é cruel, que pode matar" ${ }^{2}$. Eis a heroína do Naturalismo, cujos desejos sexuais exacerbados, manias e loucuras, compreendidos cientificamente, convertem a mulher em histérica.

Baguley $^{33}$ nota que foi a partir da década de 1860 que surgiram os primeiros livros ficcionais a tratarem, à moda naturalista, a histeria. Ao romance Germinie Lacerteux (1865), de Jules e Edmond de Goncourt, seguiu-se uma série de títulos nele inspirados: Thérèse Raquin (1867) e L'Assommoir (1877), ambos escritos por Émile Zola; La Devouée (1878), de Léon Hennique; Les Soeurs Vatard (1879), de Joris-Karl Huysmans. Nota-se, por conseguinte, um fascínio tão intenso pelo corpo e pela mente feminina no Naturalismo que se explora o mito da catastrófica sexualidade feminina:

\footnotetext{
Há um amplo corpus da literatura naturalista que se volta para estudos das "fatalidades da carne" e que tematiza o desastre capaz de ser gerado pelo corpo feminino. A insistência obsessiva com que tal tema é explorado evidencia, claramente, que estamos lidando com um mito tão imperioso quanto qualquer outro que moldou textos antigos: o mito da catastrófica sexualidade feminina. Trata-se de um mito estimulado por fisiologistas, médicos, psiquiatras contemporâneos cujos trabalhos sobre a hereditariedade, a histeria e a menstruação autenticaram e, às vezes, inspiraram diretamente dramas literários. A culpa era do corpo, do corpo da mulher, que era associado ao corpo social e ao corpo político em uma sociedade cujas apreensões confinaram a mulher ao papel de medidora e guardiã da ordem, já que sua inviolabilidade deveria ser preservada de forma ainda mais vigilante à medida que seu potencial destrutivo se tornava cientificamente demonstrável ${ }^{34}$.
}

Baguley ${ }^{35}$ menciona ainda que Hilde Olrik, ao analisar as teorias do criminologista italiano Cesare Lombroso, demonstra que os trabalhos responsáveis por comprovar a ameaça feminina imiscuíam-se com a misoginia comum à época: a mulher estava mais próxima da natureza do

32 Ibidem, p. 13.

33 BAGULEY, David. Naturalist fiction; the entropic vision, 1990.

34 Ibidem, p. 103.

35 Ibidem, p. 103. 
que o homem; era dotada de uma perversidade latente que deveria ser reprimida pela trindade maternidade-pudor-indiferença das virtudes femininas. O estudo de Lombroso sobre a perversidade erótico-histérica fundamental à mulher teria, portanto, propagado uma visão apocalíptica e aniquiladora da figura feminina. Dottin-Orsini corrobora essa perspectiva e afirma que, no âmbito literário, a mulher romântica pura e casta foi substituída por uma criatura voluptuosamente carnal:

\begin{abstract}
De qualquer maneira, no final do século [XIX], a Musa sofre estranhas metamorfoses. Vulgar para os naturalistas, ela bate nas coxas, tem suas regras (ou cólicas) e, se acontece dar à luz, é no horror e na sânie; hierática para os simbolistas, assassina com um sorriso, arrasta a saia no sangue, possui impassíveis olhos de pedra preciosa. Seja como for, é perigosa ${ }^{36}$.
\end{abstract}

Esse perigo seria decorrente da própria natureza feminina, naturalmente predisposta à histeria. A compreensão de Pinel, médico do final do século XVIII e do início do XIX, sobre a histeria ser uma "neurose genital das mulheres" ${ }^{37}$ ecoa, assim, ao longo do Oitocentos. No século XIX, a histeria continuou a ser entendida como a "feminilidade patológica e negativa", o "escândalo feminino em estado puro", a "mulher [...] exibindo (ou parecendo exibir) sua monstruosa sexualidade" ${ }^{38}$. Nesse cenário, aos sintomas corporais já descritos à época de Pinel, como distúrbios alimentares e respiratórios, anestesiamento de partes corporais, globus bystericus ${ }^{39}$ etc., acresceram-se "traços de caráter lidos como uma definição funcional da 'mulher má': sexualidade excessiva ou reduzida, comportamento namorador, mentiras e embustes, manipulação, emotividade extremada" ${ }^{40}$. As características ameaçadoras e transgressoras atribuídas às mulheres oitocentistas ganham, por conseguinte, contornos de enfermidade.

$\mathrm{O}$ interesse pelo físico e pela psique femininos pode ser encontrado não somente em obras naturalistas, mas também em histórias de vampiros, romances góticos e decadentes e livros de horror. O mito da catastrófica sexualidade feminina embasa boa parte da produção literária finissecular: "a sociedade oitocentista que gera, a partir de seus medos, personagens

36 DOTTIN-ORSINI, Mireille. A mulher que eles chamavam fatal; textos e imagens da misoginia fin-de-siècle, 1996, p. 14.

37 PINEL, Phillipe apud MITCHELL, Juliet. Loucos e medusas: o resgate da bisteria e do efeito das relações entre irmãos sobre a condição bumana, 2006, p. 29.

38 DOTTIN-ORSINI, Mireille. A mulher que eles chamavam fatal; textos e imagens da misoginia finde-siècle, 1996, p. 233-234.

39 A sensação de globo ("bola na garganta", globus hystericus) consiste na sensação de bola ou massa na faringe, não relacionada à deglutição, quando não há massa.

40 MITCHELL, Juliet. Loucos e medusas: o resgate da histeria e do efeito das relações entre irmãos sobre a condição bumana, 2006, p. 29. 
vampirescas como Lucy, de Bram Stoker, é a mesma que dá origem a histéricas, como Magdá, de Aluísio Azevedo" ${ }^{41}$.

\section{Olímpia e Magdá: heroínas gótico-naturalistas de Aluísio A zevedo}

O fascínio pela figura feminina, sobretudo pela mulher histérica, é evidenciado nos estudos de temperamento que algumas narrativas brasileiras do Naturalismo pretendiam realizar. Muitas dessas obras tiveram vida curta. Em 1888, tivemos, a exemplo, a publicação de dois romances com bastantes semelhanças: A Carne, de Júlio Ribeiro, e O Cromo, de Horácio de Carvalho. Ambos os romances desenvolvem-se em torno de heroínas que, em seu conflituoso despertar do desejo sexual, transformam-se em histéricas. Nas duas narrativas, presenciamos o caso de envolvimento passional entre uma mulher jovem e culta (Lenita, em Ribeiro; Esther, em Carvalho) e um homem maduro que domina o conhecimento científico (Barbosa, em Ribeiro; Lins Teixeira, em Carvalho), projetando na narrativa uma verdadeira diversidade de termos técnicos. O final dos romances coincide também com o rompimento amoroso dos casais: Lenita, grávida, abandona Barbosa - que se suicida; Teixeira não concretiza o ato sexual com Esther,

foge do quarto e a deixa sofrendo uma crise histérica. As duas heroínas apresentam, pois, uma história parecida, destacando-se aspectos formulares. A histérica, enquanto personagem arquetípica do Naturalismo, segue, assim, caracteres específicos: a tendência hereditária para a histeria; a condição de vítima de seu próprio estado fisiológico; a ausência de um modelo feminino materno no qual se basear; a orfandade de pai e/ou de mãe; o pouco ou nenhum senso moral; a condição de noiva de um casamento malogrado; a sexualidade irreprimível; e a representação de uma ameaça ao equilíbrio social.

Tais características ganham toques sombrios e extremamente ameaçadores no Gótico-Naturalismo. O pouco ou nenhum senso moral, a sexualidade irreprimível e a ameaça ao equilíbrio social constituem, ademais, os principais aspectos das histéricas explorados pela poética gótico-naturalista, de modo a produzir textos que, fascinados por transgressões sociais e desintegrações mentais, expõem uma visão de mundo desencantada com os valores científicos e positivistas. Exemplos de narrativas gótico-naturalistas que exploram a histeria feminina são encontrados na obra de Aluísio Azevedo, seja em seus textos subliterários, como "Músculos e nervos" (1893), seja em seus textos literários, como O bomem, evidenciando que os influxos góticos não se limitaram à obra menor do autor.

Publicado na coletânea de contos Demônios (1893), "Músculos e nervos" têm como centro a visita de Olímpia e de seu pai a um circo. Além da ausência da figura materna - não aludi-

41 SENA, Marina Faria. O Gótico-Naturalismo na literatura brasileira oitocentista, 2017, p. 63.

Universidade Federal de Santa Catarina - 2o Semestre de 2018 - 
da no conto -, a menção à figura médica e o aturdimento da moça, acentuado pela balbúrdia da plateia em êxtase, começam a delinear o temperamento feminino histérico que percorre o conto. O modo enérgico como se descreve a agitação do público, por meio de imagens que remetem à loucura e à selvageria, é essencial para intensificar a perturbação de Olímpia:

\footnotetext{
as cocotes pareciam loucas e soltavam guinchos, que ninguém entendia; das galerias trovejava um barulho infernal, e, por entre aquela descarga atroadora, só o nome do idolatrado acrobata sobressaía, exclamado com delírio por mil vozes.

- Scott! Scott!

Olímpia sentiu-se aturdida; o pai, no íntimo, arrependia-se de lhe ter feito a vontade, consentindo em levá-la ao circo, mas o médico recomendara tanto que não a contrariassem... ${ }^{42}$.
}

A descrição da cena conforma uma atmosfera perturbadora, em que as cocotes loucas, a saltar guinchos, bestializam-se, compondo um quadro assustador de um fanatismo insano. Olímpia sofre tamanho aturdimento que fica como que hipnotizada, absorta, reduzindo-se a "puro instrumento do Inconsciente ou da Vontade [carnal] que dirige o mundo" ${ }^{43}$. Angustiada e inebriada pela balbúrdia e pelo viril Scott, Olímpia responde às perguntas do pai por monossílabos - ela pouco fala ao longo do conto, o que evidencia sua desumanização: são suas ações involuntárias, comandadas por seus desejos mais sórdidos que, conforme o discurso médico finissecular, aproximam-na à figura da histérica.

Diante da última e mais perigosa acrobacia de Scott, o público se alvoraça e todo o circo respira suspense e tensão. $O$ acrobata falha ao realizar o movimento: a queda e a morte são inevitáveis - o espetáculo circense transfigura-se em espetáculo de horror. Perante a trágica cena, o local converte-se em verdadeiro pandemônio: "Nos camarotes, mulheres desmaiaram, em gritos; algumas pessoas fugiam espavoridas, como se houvesse um incêndio; outras jaziam pálidas, a boca aberta e a voz gelada na garganta" ${ }^{44}$.

Nesse ínterim, Olímpia cede a seus desejos: em espécie de transe sexual provocado pelo acrobata, a heroína, após a queda do artista, vê-se, abruptamente, diante do corpo de moribundo. Apalpa-lhe os músculos e sorve-lhe, sedenta, o sangue. Se, no início da narrativa, Olímpia estava sob jugo do pai, representante da ordem social e da proteção, no final, a jovem desprende-se dos braços paternos e sucumbe a seus desejos carnais: em uma queda vertiginosa à bestialidade, pratica uma ação situada entre a necrofilia e o vampirismo:

42 AZEVEDO, Aluísio. "Músculos e nervos", 1893, p. 188.

43 DOTTIN-ORSINI, Mireille. A mulher que eles chamavam fatal; textos e imagens da misoginia fin-de-siècle, 1996, p. 159.

44 AZEVEDO, Aluísio. "Músculos e nervos”, 1893, p. 192. 
o acrobata [...], sem acordo e quase sem vida, agonizava por terra, a vomitar sangue. Olímpia, lívida, trêmula, estonteada, quando deu por si, achou-se, sem saber como, ao lado do moribundo. Ajoelhou-se no chão, tomou-lhe a cabeça no regaço, e vergou-se toda sobre ele, procurando sentir nas faces frias o derradeiro calor daquele belo corpo escultural e másculo. E, desatinada, ofegante, apalpava-lhe o peito, o rosto, a brônzea carne dos braços, e, com um grito de extrema agonia, molhava a boca no sangue que ele expelia pela boca.

Scott teve um estremecimento geral de corpo, contraiu-se, vergou a cabeça para trás, volveu para a moça os seus límpidos olhos comovidos, agora turvados pela morte, cerrou os dentes e, num arranco supremo, soltou o gemido derradeiro.

E o corpo do acrobata escapou das mãos finas de Olímpia, inanimado ${ }^{45}$.

A heroína azevediana adquire traços típicos da figura vampiresca: "lívida", "trêmula" e "estonteada" por um singular desejo sexual, ela beija o moribundo ensanguentado, bebendo-lhe o sangue. O grito de extrema agonia emitido pela histérica revela ainda uma agonia sexual, um grito de gozo: em vez de ser fertilizada pelo sêmen branco de Scott, Olímpia farta-se do sangue vermelho do artista, sucumbindo a seus instintos bestiais.

Não encontramos a figura da mulher-vampiro ${ }^{46}$ apenas na obra subliterária de Aluísio Azevedo. Em $O$ bomem, Magdalena age, em sonho, de forma semelhante à criatura mítica. Como ocorre com Olímpia, trata-se de uma das consequências da histeria: a excessiva volúpia rompe com os protocolos sociais e morais a ponto de incutir avidez pelo sangue do homem desejado, mesmo que tal ato o arruíne.

Em $O$ bomem, o narrador propõe-se a fazer um estudo de caso. Magdalena segue os protocolos da personagem histérica: é órfã de mãe; não pode se casar com Fernando nem com Luiz; sofre agudamente com a morte de Fernando; tem como modelo feminino D. Camilla, sua tia, mulher extremamente religiosa; e luta contra seus instintos sexuais acentuados. Além disso, à moda naturalista, encontramos a personagem do médico, Dr. Lobão, como arauto da ciência. Seguindo os preceitos científicos da segunda metade do século XIX, Dr. Lobão viola as normas morais e sociais do Brasil oitocentista ao "receitar" a sua paciente o coito para evitar a tendência natural à histeria. No seguinte diálogo, observamos o diálogo estabelecido entre o médico e o Conselheiro Pinto Marques, pai de Magdalena:

O Lobão inflamou-se: - Oh! o conselheiro não podia imaginar o que eram aqueles temperamentozinhos impressionáveis!... eram terríveis, eram violentos, quando alguém tentava contrariá-los! Não pediam - exigiam! - reclamavam!

- E, se não lhes dão o que reclamam, prosseguiu, — aniquilam-se, estrangulam-

45 Ibidem, p. 192-193.

46 A mulher como vampiro constitui uma personagem antiga que perpassa a cultura ocidental até a contemporaneidade: na Antiguidade, a exemplo, as Lâmias ou as Estriges eram criaturas femininas que devoravam os recém-nascidos, a Empuse grega era matadora de homens. 
-se, como leões atacados de cólera! É perigoso brincar com a fera que principia a despertar... O monstro deu já sinal de si; e, pelo primeiro berro, você bem pode calcular o que não será quando estiver de veras assanhado!

- Valha-me Deus! suspirou o pobre conselheiro, que hei de eu fazer, não dirão?

— Ora essa! Pois já não lhe disse? É casar a rapariga quanto antes!

- Mas com quem?

- Seja lá com quem for! O útero, conforme Platão, é uma besta que quer a todo o custo conceber no momento oportuno; se lho não permitem — dana! Ora aí tem!

$[\ldots]$

- Casamento é um modo de dizer, eu faço questão é do coito! - Ela precisa de homem! ${ }^{47}$.

O conselho do médico não é seguido. Magdá torna-se uma histérica, com crises que preenchem diversas páginas do livro: "ficava aborrecida, triste, sem apetite; apareciam-lhe nevralgias, acompanhadas de grande sobre-excitação nervosa. Então, qualquer objeto ou qualquer fato repugnante a indispunha de um modo singular" ${ }^{48}$. Para amenizar a doença da filha, o conselheiro e a família mudam-se do agitado bairro de Botafogo para uma chácara na Tijuca. Tal deslocamento, no entanto, não reduz o sofrimento da heroína, mas o acentua, fato já adiantado no momento que adentram a nova moradia:

Para chegar à casa, tinha-se de atravessar uma longa e tenebrosa alameda de mangueiras, que começava logo no portão da entrada e se ia estendendo por ali acima, lúgubre como um caminho de cemitério. Era triste aquilo com os seus altos muros de pedra e cal, pesados, cobertos de limo, e transbordantes de copas d'árvores velhas. O casarão, olhado pelas costas ou pelo flanco esquerdo, deixava-se ver em toda a sua grosseira imponência [...]. Metia aflição entrar lá: um pavoroso silêncio de igreja abandonada enchia os enormes quartos nus e enxovalhados de pó; um ar frio e encanado, como o ar de corredores de claustro, enregelava e oprimia o coração naqueles longos aposentos sem vida. Tudo aquilo transpirava cheiro de velhice, cheiro de moléstia; sentiam-se a friagem da morte e a fedentina úmida das catacumbas $^{49}$.

O casarão, arruinado e abandonado, faz paralelo aos castelos medievais do Gótico Setecentista. Trata-se, de fato, do principal locus borribilis do Gótico Brasileiro. O narrador constrói um ambiente degradado pelo tempo e pela ação natural, arquitetando uma atmosfera lúgubre e mortuária. Para tal, são essenciais os vocábulos do campo semântico da morte, da ruína e do claustro. Como o castelo dos romances góticos, o casarão do conselheiro servirá de locus para os sofrimentos físicos e psicológicos da heroína. Essa mesma residência ainda é palco da morte de D. Camilla e dos crimes de Magdalena: o assassinato de seu objeto de desejo, o cavouqueiro

47 Idem, 1887, p. 67-69.

48 Ibidem, p. 55.

49 Ibidem, p. 108. 
Luiz, e da esposa deste. A primeira caracterização da nova moradia dos Pinto Marques, um autêntico locus borribilis, anuncia, pois, a ruína da família.

Culpada pela impossibilidade de controlar seus instintos sexuais, Magdá recorre à religião. Ao apelar à religiosidade em vez de dirigir-se à ciência para amenizar seu padecimento, ela rompe com estrito caráter científico que o Naturalismo, na perspectiva da crítica brasileira, deveria ter. A personagem vê-se, destarte, obrigada a praticar hábitos pios e a entoar fervorosas orações, recitando diariamente aquela que sua tia lhe ensinara:

Jesus, filho de Maria, Príncipe dos céus e Rei na terra, senhor dos homens, amado meu, esposo de minha alma, vale-me tu, que és a minha salvação e o meu amor! Esconde-me, querido, com o teu manto, que o leão me cerca! Protege-me contra mim mesma! esconjura o bicho imundo que habita minha carne e suja minha alma! - Salva-me! Não me deixes cair em pecado de luxúria, que eu sinto já as línguas do inferno me lambendo as carnes do meu corpo e enfiando-se pelas minhas veias! Vale-me, esposo meu, amado meu! Vou dormir à sombra da tua cruz, como o cordeirinho imaculado, para que o demônio não se aproxime de mim! Amado do meu coração, espero-te esta noite no meu sonho, deitada de ventre para cima, com os peitos bem abertos, para que tu me penetres até ao fundo das minhas entranhas e me ilumines toda por dentro com a luz do teu divino espírito! Por quem és, conjuro-te que me não faltes, porque, se não vieres, arrisco a cair em poder dos teus contrários, e morrerei sem estar no gozo da tua graça! Vem ter comigo, Jesus! Jesus, filho de Deus, senhor dos homens, Príncipe dos céus e Rei na terra! Vem, que eu te espero. Amém ${ }^{50}$.

O apelo à divindade cristã é, porém, transgressor e herético. Enquanto a Igreja via o sexo como um entrave para a perfeita evolução espiritual, a oração recitada pela personagem invoca justamente um Jesus que penetra a devota "deitada de ventre para cima, com os peitos bem abertos", em uma evidente sugestão de cópula. Para tal compreensão, corroboram, ademais, os vocativos clamados pela crente, como "amado meu" e "esposo da minha alma". A religião, como no Gótico, é aqui pervertida e incapaz de promover a redenção do pecador. A presença divina é substituída pela presença material da carne, revelando uma cosmovisão negativa e pessimista. No Gótico-Naturalismo, nem ciência nem religião são capazes de cercear a bestialidade humana: o ser humano está fadado à degeneração. A histeria de Magdá nada mais é do que o grito da Natureza contra a civilização, clamor este que, antes de concretizar a destruição física e psicológica da personagem, manifesta-se em sonhos e alucinações, como aquele em que ela, como Olímpia, sorve o sangue de seu amante:

- Meu Deus, como estás tão pálida! disse ele [Luiz], pousando-a à sombra dos bambus - Vou buscar-te um pouco d'água ali à fonte. Espera um instante; eu volto já.

50 Ibidem, p. 90-91. 
- Não, não! gemeu a moça, segurando-o com ambas as mãos. - Não te afastes de mim! Não é de água que eu preciso, é de um pouco de vida! Sinto fugirem-me as últimas forças! Eu preciso de sangue!

E fazia-se cor de cera, e fechava os olhos, e entreabria os lábios, como um órfãozinho abandonado que morre à mingua do leite materno.

$[\ldots]$

Ela soergueu as pálpebras e murmurou baixinho, quase imperceptivelmente:

- Sangue! sangue! sangue, senão eu morro!...

- Ah! fez o moço com vislumbre. E, sem sair donde estava, quebrou um espinho de palmeira e com ele picou uma veia do braço. - Toma! disse, apresentando à amante a gota vermelha que havia orvalhado na brancura da sua carne - Bebe!

Magdá precipitou-se avidamente sobre ela e chupou-a com volúpia. Não se ergueu logo; continuou a sugar a veia, conchegando-se mais ao amigo, agarrando-se-lhe ao corpo, toda grudada nele, apertando os olhos, dilatando os poros, arfando, suspirando desafogadamente pelas narinas, como se matasse uma velha sede devoradora. [...]

Magdá readquiria por encanto a frescura, a beleza e a saúde, que havia perdido nos últimos anos. ${ }^{51}$

Na cena, à protagonista azevediana associam-se caraterísticas típicas do vampiro: pálida e sensual, exerce grande influência sobre Luiz, sua presa. O sangue deste alimenta e vivifica Magdá: a magreza; a palidez; "os olhos muito fundos; as faces cavadas e a pele estalando em pequeninas rugas de porcelana velha" ${ }^{\prime 52}$ - sua degrada e real compleição física - são substituídos pela beleza e pela saúde do sonho vampírico.

$\mathrm{O}$ aniquilamento da vitalidade de Luiz não se limita à imaginação da protagonista. Delirante, impedida de se casar e de manter relações sexuais com o cavouqueiro, ela comete duplo homicídio: assassina seu amante e a esposa deste. Objetivando o efeito estético do horror e da repulsa, o narrador gótico-naturalista descreve minuciosamente a consequência da ação atroz e sádica de Magdalena:

Fez-se um silêncio gélido, em que se ouvia pendular na alcova de Magdá o seu pequeno regulador de bronze; mas no fim de alguns instantes os pobres noivos, que pareciam cada vez mais sobreexcitados, puseram-se a mexer com a mandíbula inferior, contraindo os músculos da face; e daí a pouco tinham rápidos estremecimentos convulsivos, que lhes agitavam o corpo inteiro, de instante a instante, violentamente.

Luiz quis falar e não pôde; apenas gorgolejou uns bulidos guturais.

Magdá ria-se, olhando as caretas convulsivas que ele e a mulher faziam. Esta, agonia$\mathrm{da}$, levava simultaneamente as mãos à garganta e ao estômago, sem poder gritar, tão contraída tinha já a laringe.

51 Ibidem, p. 232-234.

52 Ibidem, p. 265. 


\begin{abstract}
Repetiam-se os espasmos com mais intensidade, acompanhados de feias agitações tetânicas. O cavouqueiro estorcia-se na cadeira, rilhando os dentes e tomado de uma ereção dolorosíssima.

Quando Justina voltou, encontrou-os por terra, a estrebucharem; roxos, as pupilas dilatadas, os membros hirtos, os queixos cerrados.

A criada soltou um grito, atirou com a bilha d'água e os copos, e saiu a berrar.

Com este barulho, Luiz teve um acesso mais forte e retesou-se todo, vergando-se para trás, a ponto de encostar a cabeça na coluna vertebral.

E roncava, escabujando horrorosamente ${ }^{53}$.
\end{abstract}

Vítima de sua própria condição de mulher, como afirmavam os cientistas da segunda metade do século XIX, Magdá torna-se uma criatura monstruosa. Semelhante a Olímpia, desvencilhada da subjugação de uma figura masculina e impossibilitada de concretizar seu apetite sexual, sorve a vida de seu objeto de desejo, terminando, à guisa do Gótico-Naturalismo, louca e arruinada: "Ficou lá dentro [na prisão] sozinha, a roncar como uma fera encarcerada. O pai viu fecharem-lhe a jaula, mais sucumbido do que se aquela porta fosse a lousa de um túmulo" 54 .

Magdalena e Olímpia vivenciam, portanto, a trajetória da queda, isto é, "o espetáculo - ou a agonia - da mulher decaída: seu declínio, suas humilhações, a perda de seu eu e de sua identidade, depois de uma perda catastrófica de sua virgindade ou de sua honra"'55. Uma queda que, na poética gótico-naturalista, assume tons ainda mais lúgubres e mais sombrios. Voluptuosa, insana, vampírica e fatal, ambas as personagens exemplificam o tratamento dado à figura feminina na ficção brasileira finissecular, em especial naquela afiliada à poética gótico-naturalista. Contrariando o lema positivista de ordem e progresso, desvela-se que a humanidade está fadada ao caos e à involução.

\title{
Referências
}

ANOLIK, Ruth Bienstock. Introduction: The Dark Unknown. In. ; HOWARD, Douglas L. (Eds.). The Gothic other: racial and social constructions in the literary imagination. Jefferson: McFarland \& Co., 2004. p. 1-14.

AZEVEDO, Aluísio. Músculos e nervos. In. . Demônios. São Paulo: Teixeira \& Irmão, 1893. p. 186-193.

AZEVEDO, Aluísio. O cortiço. São Paulo: Martins Editora; Brasilia: INL, 1975.

53 Ibidem, p. 359-360.

54 Ibidem, p. 374.

55 BAGULEY, David. Naturalist fiction; the entropic vision, 1990, p. 105. Tradução nossa. 
AZEVEDO, Aluísio. O bomem. Rio de Janeiro: Tipografia de Adolpho de Castro Silva \& Companhia, 1887.

BAGULEY, David. Naturalist fiction; the entropic vision. Cambridge: Cambridge University Press, 1990.

BOSI, Alfredo. História concisa da literatura brasileira. São Paulo: Cultrix, 2015.

BOTTING, Fred. Gothic. 2a ed. London: Routledge, 2014.

BRAYNER, Sonia. Naturalismo: uma ficção em crise. In. . Labirinto do espaço romanesco: tradição e renovação da literatura brasileira, 1880 a 1920. Rio de Janeiro: Civilização Brasileira; Brasília: INL, 1979. p. 23-50.

CROW, Charles. Jack London's The Sea Wolf as Gothic Romance. In. SMITH, Allan Lloyd (Org.). Gotbick Origins and Innovations. Amsterdam: Rodopi, 1994. p. 123-131.

DELUMEAU, Jean. História do medo no Ocidente; 1300 - 1800. Tradução de Maria Lucia Machado. Tradução de notas de Heloísa Jahn. São Paulo: Companhia das Letras, 2001.

DOTTIN-ORSINI, Mireille. A mulher que eles chamavam fatal; textos e imagens da misoginia fin-de-siècle. Rio de Janeiro: Rocco, 1996.

FRANÇA, Júlio. Introdução. In. (Org.). Poéticas do mal: a literatura do medo no Brasil (1840-1920). Rio de Janeiro: Bonecker, 2017. p. 19-35.

MEIRELES, Alexander. O admirável mundo novo da república velba: o nascimento da ficção científica brasileira no começo do século XX. 2008. 193 f. Tese (Doutorado em Ciência da Literatura - Faculdade de Letras, Universidade Federal do Rio de Janeiro, Rio de Janeiro, 2008.

MITCHELL, Juliet. Loucos e medusas: o resgate da histeria e do efeito das relações entre irmãos sobre a condição humana. Tradução de Maria Beatriz Medina. Rio de Janeiro: Civilização Brasileira, 2006.

PEIXOTO, Afrânio. A originalidade de Álvares de Azevedo. Revista Nova, São Paulo, ano I, n. 3, 15 set. 1931 , p. 355-374.

PEREIRA, Lúcia Miguel. História da literatura brasileira: prosa de ficção: de 1870 a 1920. Belo Horizonte: Itatiaia; São Paulo: Edusp, 1988.

RIBEIRO, Júlio. A carne. São Paulo: Livraria Teixeira, 1896.

SENA, Marina Faria. O Gótico-Naturalismo na literatura brasileira oitocentista. $2017.99 \mathrm{f}$. Dissertação (Mestrado em Teoria da Literatura e Literatura Comparada) - Instituto de Letras, Universidade do Estado do Rio de Janeiro, Rio de Janeiro, 2017.

SODRÉ. Nelson Werneck. O Naturalismo no Brasil. Rio de Janeiro: Civilização Brasileira, 1965.

STAËL, Mme de. Sobre as literaturas do norte e do meio dia. In: SOUZA, Roberto Acízelo de (Org.). Uma ideia moderna de literatura: textos seminais para os estudos literários (16661922). Argos: Rio de Janeiro, 2011. p. 81-83.

STEVENS, David. The Gothic tradition. Cambridge: Cambridge University Press, 2000. 
SÜSSEKIND, Flora. Tal Brasil, qual romance?. Rio de Janeiro: Achiamé, 1984.

VASCONCELOS, Sandra. Sentidos do demoníaco em José de Alencar. Ilba do Desterro, v. 62, p. 271-292, 2012.

Submissão: 10/05/2020

Aceite: $09 / 07 / 2020$

https://doi.org/10.5007/2176-8552.2018n26p78

Esta obra foi licenciada com uma Licença Creative Commons Atribuição-NãoComercial 4.0 Internacional. 